\title{
Investigations into the Morphometric Characteristics of Obibia Drainage Basin, Awka Urban Area, Nigeria
}

\author{
Emma E. Ezenwaji' ${ }^{1}$ Emmanuel 0. Nwabineli², Philip 0. Phil-Eze ${ }^{3}$ \\ ${ }^{1}$ Nnamdi Azikiwe University, Awka, Nigeria \\ ${ }^{2}$ Akanu Ibiam Federal Polytechnic, Unwana, Nigeria \\ ${ }^{3}$ University of Nigeria, Nsukka, Nigeria \\ Email: emmaezenwaji@gmail.com
}

How to cite this paper: Ezenwaji, E.E., Nwabineli, E.O. and Phil-Eze, P.O. (2018) Investigations into the Morphometric Characteristics of Obibia Drainage Basin, Awka Urban Area, Nigeria. Open Journal of Modern Hydrology, 8, 1-12.

https://doi.org/10.4236/ojmh.2018.81001

Received: October 20, 2017

Accepted: December 22, 2017

Published: December 25, 2017

Copyright $\odot 2018$ by authors and Scientific Research Publishing Inc. This work is licensed under the Creative Commons Attribution International License (CC BY 4.0). http://creativecommons.org/licenses/by/4.0/

\section{Open Access}

\begin{abstract}
The aim of the study was to investigate the morphometric characteristics of Obibia drainage basin which is wholly located within the Awka Capital territory of Anambra State, Nigeria. The basin was delineated with conventional method from topographic map (Udi SW) on the scale of 1:50,000 published by Federal Survey office. Field survey was conducted for 9 months between April and December 2015 and data were obtained on linear, areal and relief aspects of the basin to ascertain the morphometric characteristics of the basin. Principal Component Analysis (PCA) reduced our 19 variables into 5 while Principal Component Regression (PCR) was employed to reveal the relative contributions of morphometric variables. Result shows a bifurcation Ratio $\mathrm{R}$ $(\mathrm{Rb})$ of 3.00 around the month of the river basin indicating higher risk of flooding. The relationship between mean stream length and stream order shows that order 2 drifts too far away from straight line on plotted graph suggesting some structural imbalances. The study recommends proper urban land use planning within the basin that would preserve the natural condition of the basin.
\end{abstract}

\section{Keywords}

Morphometry, Basin, Relief, River, Land Use

\section{Introduction}

The problems posed by the morphometric characteristics of some urban river basins in Nigeria are widely recognized. In a comparative study of Ogunpa and Ogbere drainage basin in Ibadan, Ajibade, Ifebiyi, Iroye and Ogenteru [1] con- 
cluded that the peculiar morphometric properties of Ogunpa was its compactness that produces sharp hydrographic peak as a result of high bifurcation ratio. They further concluded that Ogunpa had higher drainage density, higher relief ratio, than Ogbere etc. all which usually result in incidences of flooding that have been the central problem of the basin as wells as higher erosive capacity and sediment yields which further disposes the basin to flooding. These properties were not found in Ogbere basin, making it less prone to extremely hydrological and geomorphic problems. Furthermore Eze and Effiong [2] in examining the morphometric parameters of the Calabar river basin and implications for hydrologic process, noted that low values of drainage density, stream frequency and drainage intensity imply that the surface runoff is not quickly removed from the basin making it susceptible to flooding and existence of a marshy environment.

Again Abua and Abua [3] working in Diobu Port Harcourt interrogated the hydraulic characteristics and relationship of the Oromineke basin and found that a strong association existed between suspended sediment yield and water discharge. The study revealed that the basin has a mean bifurcation ratio of 3.0 and a very high compactness ratio of 7.213 which indicated that the streams in the basin are close to one another and implied that the basin is flooded with patchy swampy locations.

Furthermore, Uzor studied the Nyaba and Ekulu drainage basins in Enugu urban area and determined that high sediment yield of Nyaba basin has considerably raised the Nyaba river channel resulting in flash floods that occasionally destroy lives and property especially along the riparian environment.

The influence of high population, as well as, physical development of the urban area affects in various ways the morphometry of the urban drainage basin. However, despite these various studies of drainage basins located in urban areas, many more of such basins are yet to be studied to determine the influence of urban development on various morphometric parameters of such basins. One of such basins that have not been studied is the Obibia drainage basin despite the fact that it is located in the following Local Government Area (LGA) within the Awka Capital Territory: Anaocha, Njikoka and Awka South. However, over 80\% of the basin is located in Awka South L.G.A.

\section{Material and Method}

\subsection{Area of Study}

The Obibia drainage basin is located between Latitudes $6^{\circ} 05^{\prime} \mathrm{N}$ and $6^{\circ} 13^{\prime} \mathrm{N}$ and Longitudes $7^{\circ} 01^{\prime} \mathrm{E}$ and $7^{\circ} 09^{\prime} \mathrm{E}$. It has an area of $84 \mathrm{sq} \cdot \mathrm{km}$ and covers parts of Anaocha, Njikoka and Awka South L.G.A (Figure 1).

The climate is hot wet equatorial with average maximum temperature of $28^{\circ} \mathrm{C}$ and average minimum of $24^{\circ} \mathrm{C}$ which depend on the season of the year. Rainfall is experienced for 8 months of the year from March to November, while dry season lasts from December to March. Total mean annual rainfall is $1800 \mathrm{~mm}$, 


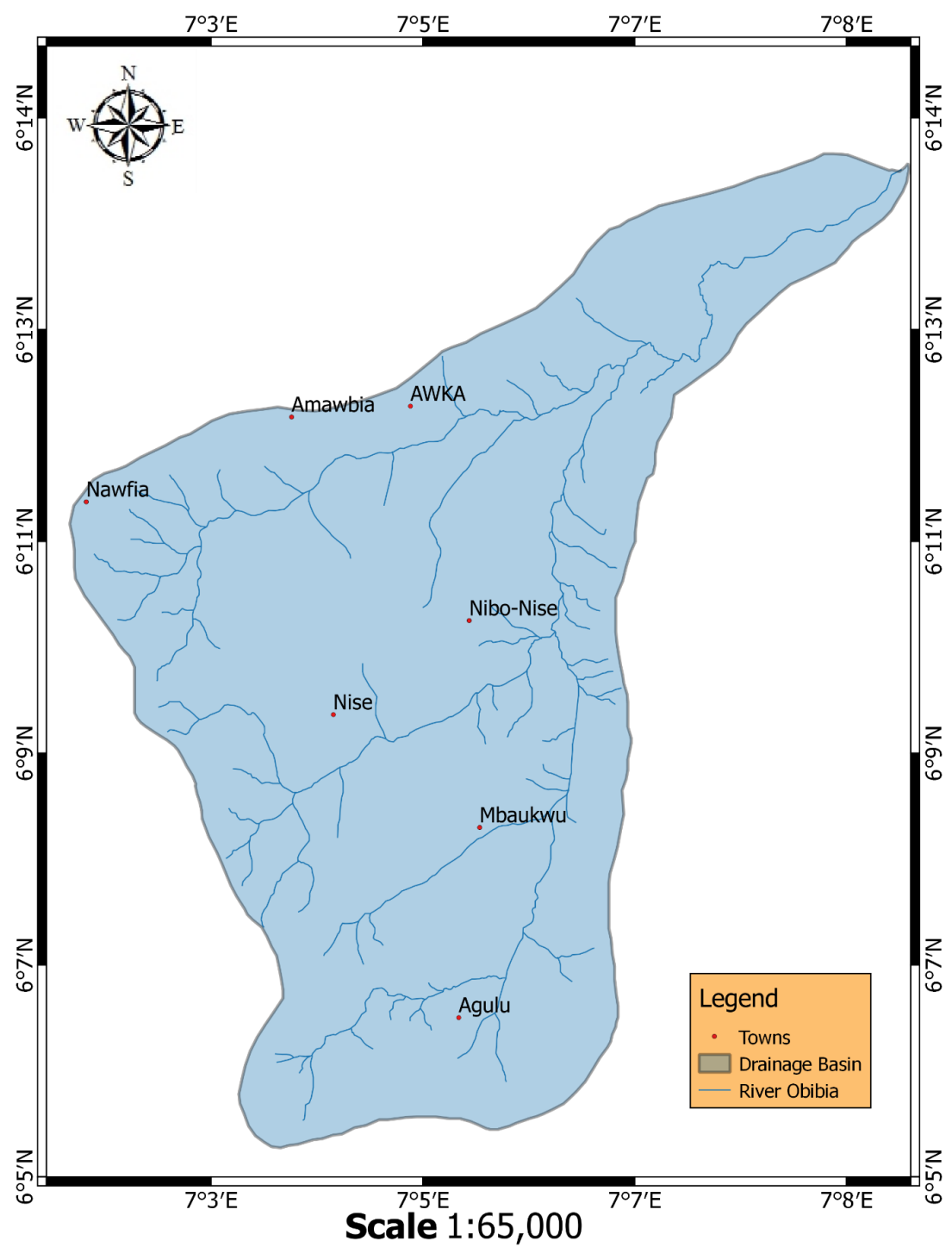

Figure 1. Map of River Obibia Basin in Anambra State.

while the vegetation is rainforest, but largely disturbed by urbanization and other human actions, thus creating a derived savanna as patches of outliers within the study area.

In terms of geology, the Obibia Basin lies mainly within Imo clay shale that runs from southern Igala in Kogi State. However, the Bende-Ameki formation which is sandy formation dominates the western and south-western parts of the area. This formation (Bende-Ameki) is a productive aquifer that is suitable for the exploitation of water though ground source. Some parts of the basin around Isiagu and Ezinator communities are dominated by Imo clay shale that is poor in the production of ground water. In the eastern parts of the basin, around AguAwka and Amansea, the major geological composition is the Ebenebe formation. The basin lies on Awka-Orlu upland and partly on the flood plain of Manu River. The plain area has an average elevation of $129.5 \mathrm{~m}$ while the upland area has a general elevation of $250 \mathrm{~m}$ to $500 \mathrm{~m}$. 
The basin, which is being located mainly in the urban area, has a high population density and many physical development activities which are likely to negatively affect the morphometry of the basin. The drainage pattern of the basin is essentially dendritic.

\subsection{Data Collection}

The basin was delineated from the UDI S.W topographical map on the scale of 1:50,000 published by the Federal survey office. The processes of geo-referencing and digitisation were subsequently employed (Figure 1). Field survey was conducted for 9 months between April and December 2015 and data were obtained on 19 linear, areal and relief properties of the basin consisting of eight linear, six Areal and five relief aspects (Table 1).

Principal Component Analysis (PCA) and Principal Component Regression (PCR) were the major statistical techniques employed for analysis. PCA, reduced the 19 variables into 5 orthogonal components. After this, the principal component loadings were run from the five selected principal components. Subsequently,

Table 1. Nineteen morphometric parameters of Obibia Basin and their methods of calculation.

\begin{tabular}{|c|c|c|c|}
\hline $\mathbf{S} / \mathbf{N}$ & Morphometric Parameters & Derivation Procedure & Reference \\
\hline 1. & Stream order $(\mathrm{u})$ & Hierarchical order & Strahler, 1964 \\
\hline 2. & Stream length $(\mathrm{Lu})$ & Length of the stream & Horton, 1945 \\
\hline 3. & Basin length $(\mathrm{Lu})$ & This is the straight line from the mouth of the basin to the farthest point on the basin perimeter & Schumn, 1963 \\
\hline 4. & Main stream length $(\mathrm{km})$ & This is the length of the principal drainage & Schumn, 1963 \\
\hline 5. & Main stream length $(\mathrm{km})$ & Total stream lengths in the basin divided by total number of streams & Schumn, 1963 \\
\hline 6. & Total stream length $(\mathrm{km})$ & This is the total length of all the tributaries and the principal drainage & Schumn, 1963 \\
\hline 7. & Basin perimeter $(\mathrm{p})$ & This is the outer boundary of the drainage basin that encloses its area & Schumn, 1956 \\
\hline 8. & Bifurcation ration $\left(\mathrm{R}_{\mathrm{b}}\right)$ & $\begin{array}{l}\mathrm{R}_{\mathrm{b}}=\mathrm{Nu} / \mathrm{Nu}+1 \text {, where } \mathrm{u}=\text { total no of streams of order " } \mathrm{u} \text { ", } \mathrm{Nu}+1=\text { No of segment of the } \\
\text { next higher order }\end{array}$ & Schumn, 1963 \\
\hline
\end{tabular}

\section{AREA PROPERTIES}

1. $\quad$ Basin Area (A) $\quad$ Area = map scale counted squares

2. Drainage Density (Dd) EL/A where $\mathrm{L}=$ total length of all streams; $\mathrm{A}=$ Basin Area

3. Stream frequency (Fs) N/A where $\mathrm{N}=$ Total no of streams; $\mathrm{A}=$ Area of the basin

4. Form factor

5. Circulatory Ration $(\mathrm{Rc})$

6. Elongation Ration ( $\mathrm{Re})$

\section{RELIEF PROPERTIES}

1. Basin Relief $(\mathrm{H})$

Vertical distance between the lowest and highest points in the basin ( $\max ^{1} \mathrm{H}$-min. $\mathrm{H}$ )

Schumn, 1956

2. Relief Ration (Rh)

$\mathrm{H} / \mathrm{Lb}$ where $\mathrm{H}=$ basin relief, $\mathrm{Lb}=$ Basin length

3. Max Relief $(\operatorname{maxH})$

The highest point value of elevation in a drainage basin

4. Min Relief ( $\operatorname{minH})$
Schumn, 1956

Schumn, 1956

Gregory and Walling, 1973

Horton, 1945

Horton, 1945

Horton, 1932

Horton, 1932

Schumn, 1959

Schumn, 1956 
the Multiple Linear Regression (MLR) was then run on the selected loadings. In this analysis, the defining loadings known as the Component Defining Variable (CDV) were employed. Basin area was the dependent variable while other morphometric variables are independent variables. With this, a PCR equation was produced which was used to interpret the result of the analysis.

\section{Result and Discussion}

\subsection{Result}

The result of the investigation into the linear properties of the basin including the bifurcation ratio, aerial and relief properties are presented in Tables 2-4.

In analysing the linear, areal and relief properties of the basin, PCA (CDV) was employed. Table 5 shows the labelling and coding of the Properties.

The relationship between streams numbers $\left(\mathrm{N}_{\mathrm{u}}\right)$ and stream order $(\mathrm{U})$ as well as the regression of the logarithm of stream numbers $\log \mathrm{N}_{\mathrm{u}}$ against stream order were plotted as shown Figure 2 and Figure 3.

Table 2. Linear properties of the basin.

\begin{tabular}{cccccc}
\hline $\begin{array}{c}\text { Stream order } \\
(\mathrm{u})\end{array}$ & $\begin{array}{c}\text { Stream number } \\
(\mathrm{Nu})\end{array}$ & $\begin{array}{c}\text { Total stream } \\
\text { lengths }\end{array}$ & $\begin{array}{c}\text { Mean stream } \\
\text { lengths }\end{array}$ & $\begin{array}{c}\text { Long } \\
\text { Nu }\end{array}$ & $\begin{array}{c}\text { Log } \\
\text { Lu }\end{array}$ \\
\hline 1. & $64(77.1 \%)$ & $\mathrm{Lu}(\mathrm{km}) 56.5$ & 0.88 & 1.806 & 1.752 \\
2. & $15(18.1 \%)$ & 15 & 1 & 1.176 & 1.176 \\
3. & $3(3.6 \%)$ & 20 & 6.67 & 0.447 & 1.031 \\
4. & $1(1.2 \%)$ & 10.75 & 10.75 & 0 & 1.031 \\
Total & 83 & 102.25 & & & \\
Bifurcation ration $\left(\mathrm{R}_{\mathrm{b}}\right)$ of the basin & & & & \\
$1^{\text {st }}$ Order & $2^{\text {nd }}$ Order/ & $3^{\text {rd }}$ Order/ & Mean bifurcation Ration & & \\
$2^{\text {nd }}$ Order & $3^{\text {rd }}$ Order & $4^{\text {th }}$ Order & R & & \\
4.27 & 5.00 & 3.00 & 4.09 & & \\
4
\end{tabular}

Table 3. Areal properties of the basin.

\begin{tabular}{ccc}
\hline S/N & Morphometric Properties & Calculated Values \\
\hline 1. & Basin Area $\left(\mathrm{Km}^{2}\right)$ & 84 \\
2. & Perimeter $(\mathrm{km})$ & 50.5 \\
3. & Basin length $(\mathrm{km})$ & 18.25 \\
4. & Drainage Density & 1.22 \\
5. & Stream Frequency & 0.99 \\
6. & Elongation Ratio & 0.57 \\
7. & Form Factor & 0.25 \\
8. & Calculatory Ratio & 0.41 \\
9. & Compaction Coefficient & 1.55 \\
\hline
\end{tabular}


Table 4. Relief properties of Obibia Basin.

\begin{tabular}{ccc}
\hline S/N & Morphometric Properties & Calculated Values \\
\hline 1. & Basin Relief & 0.6 \\
2. & Relief Ration & 0.03 \\
3. & Basin Slope & 1.03 \\
4. & Max Basin Relief & 0.75 \\
5. & Min Basin Relief & 0.15 \\
\hline
\end{tabular}

Table 5. Labelling and coding of the morphometric properties of the basin.

\begin{tabular}{|c|c|c|c|}
\hline $\mathrm{S} / \mathrm{N}$ & Variable Label & Variable Code & Variable Description \\
\hline 1. & SOR & $\mathrm{X}_{1}$ & Stream Order \\
\hline 2. & SLE & $\mathrm{X}_{2}$ & Stream Length \\
\hline 3. & BLE & $\mathrm{X}_{3}$ & Basin Length \\
\hline 4. & MSL & $\mathrm{X}_{4}$ & Main Stream Length \\
\hline 5. & MEL & $\mathrm{X}_{5}$ & Main Stream Length \\
\hline 6. & TSL & $\mathrm{X}_{6}$ & Total Stream Length \\
\hline 7. & BAP & $\mathrm{X}_{7}$ & Basin Perimeter \\
\hline 8. & BFR & $\mathrm{X}_{8}$ & Bifurcation Ratio \\
\hline 9. & BAR & $\mathrm{X}_{9}$ & Basin Area \\
\hline 10. & DRD & $\mathrm{X}_{10}$ & Drainage Density \\
\hline 11. & SRF & $\mathrm{X}_{11}$ & Stream Frequency \\
\hline 12. & FFA & $\mathrm{X}_{12}$ & Form Factor \\
\hline 13. & CRA & $\mathrm{X}_{13}$ & Circulatory Ratio \\
\hline 14 & ERA & $\mathrm{X}_{14}$ & Elongation Ration \\
\hline 15. & BRE & $\mathrm{X}_{15}$ & Basin Relief \\
\hline 16. & RRA & $\mathrm{X}_{16}$ & Relief Ratio \\
\hline 17. & BSL & $\mathrm{X}_{17}$ & Basin Slop \\
\hline 18. & MAR & $\mathrm{X}_{18}$ & Max Relief \\
\hline 19. & MIR & $\mathrm{X}_{19}$ & Min Relief \\
\hline
\end{tabular}

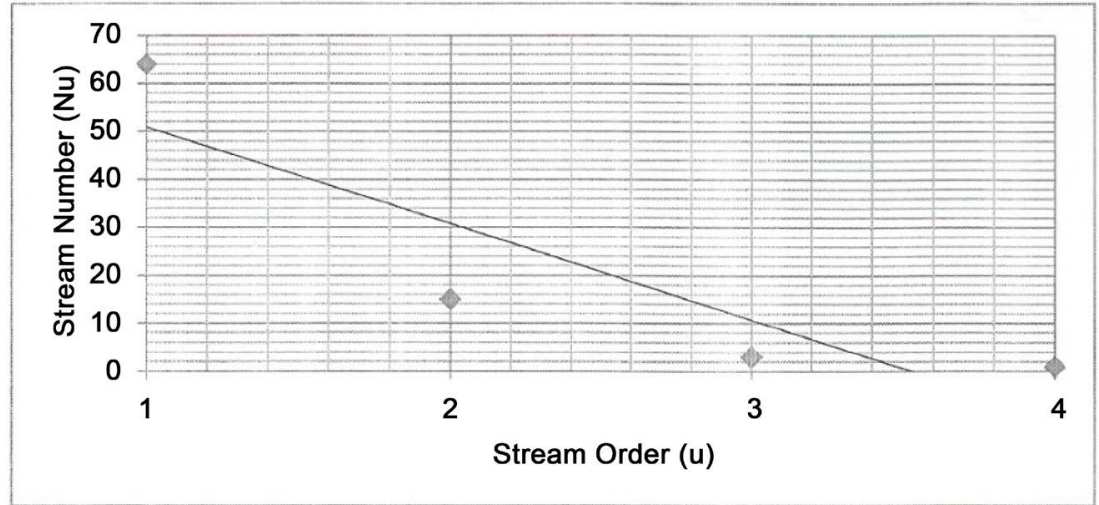

Figure 2. Relationship between stream numbers $(\mathrm{Nu})$ and Stream Order $(\mathrm{u})$ for Obibia River Basin. 


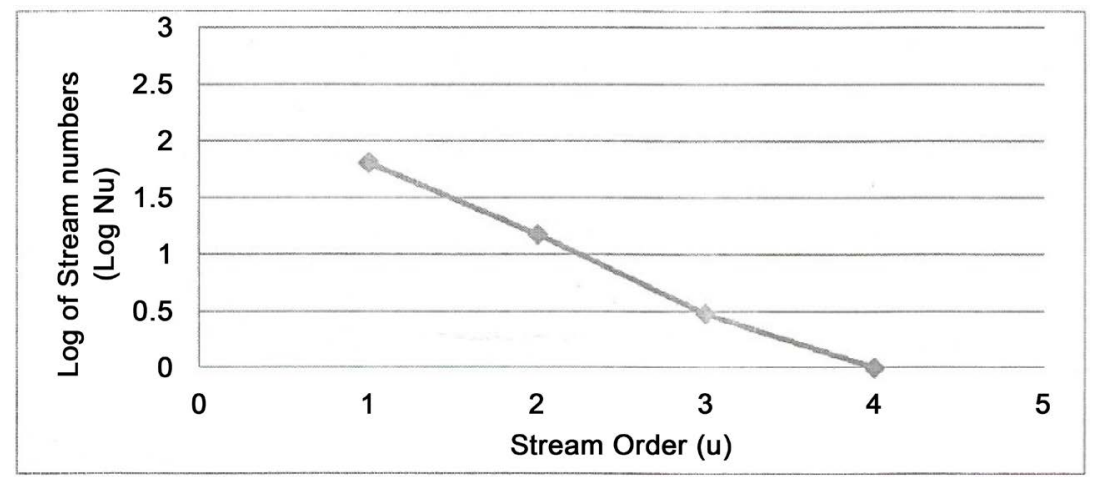

Figure 3. Regression of logarithm of stream numbers ( $\log \mathrm{Nu}$ ) against Stream Order (u) for Obibia River Basin.

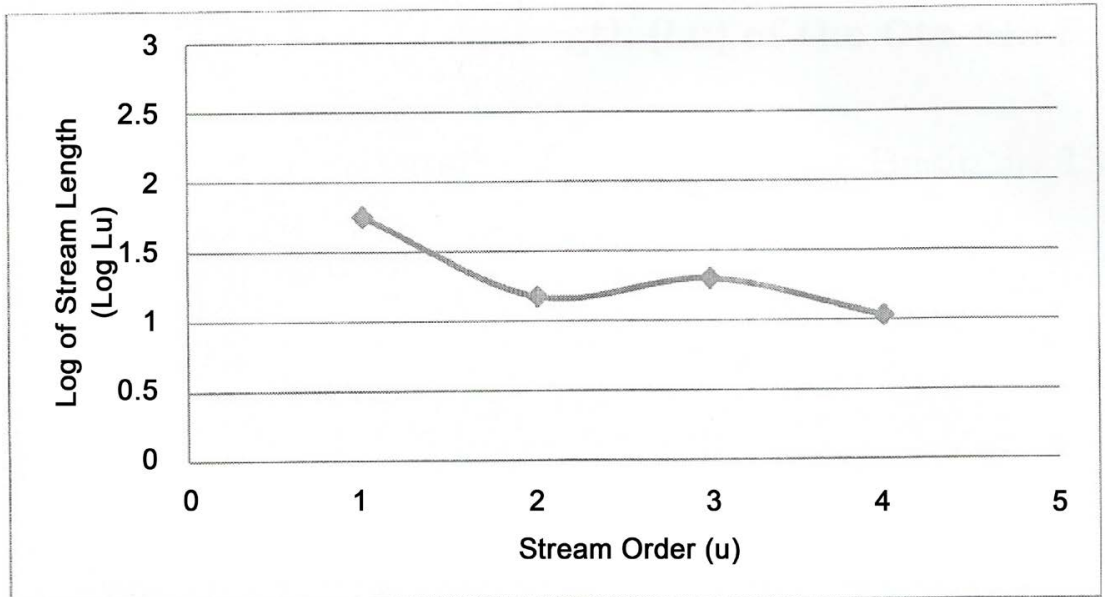

Figure 4. Regression of logarithm of stream length (Log Lu) versus Stream Order (u) for Obibia River Basin.

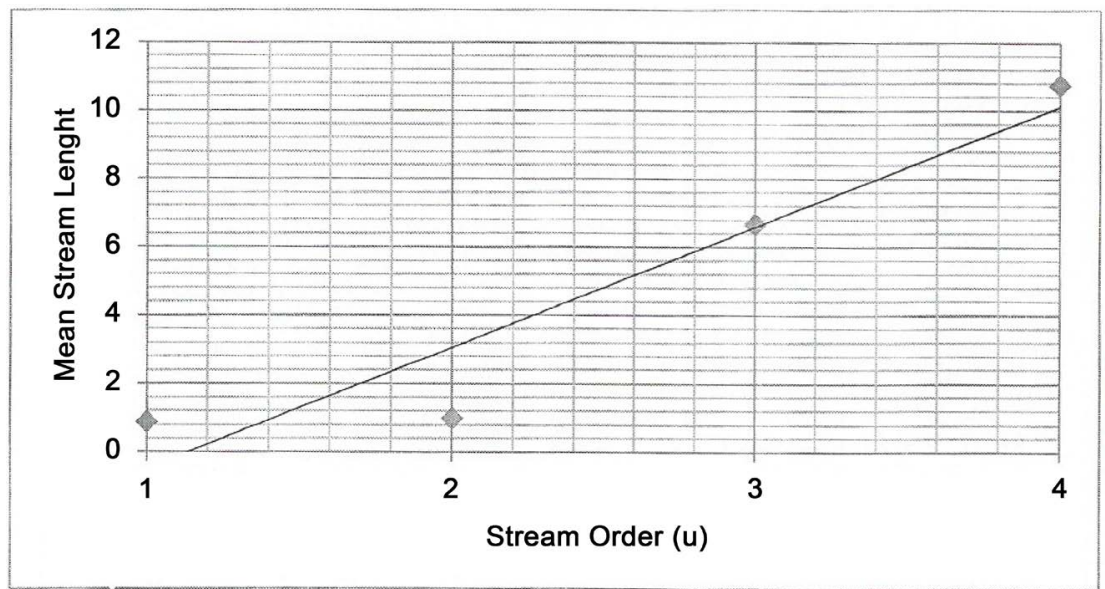

Figure 5. Relationship between mean stream length and Stream Order (u) for Obibia River Basin.

Furthermore, regression of logarithm of stream length $\log \left(\mathrm{L}_{\mathrm{u}}\right)$ and stream order $(\mathrm{U})$ as well as relationship between mean stream length and stream order (U) for the basin were plotted and shown in Figure 4 and Figure 5. 
In analysing the morphometric data, they were first transformed into a matrix of standard scores after which the correlation analysis was performed on the transformed data (both the standardized data and Multiple correlation matrices were not shown). However, it was noticed that most of the properties were highly correlated. The problem of intercorrelation provoked us to subject the morphometric data to PCA in order to have a parsimonious number of clearly defined orthogonal (unrelated) factors that can explain the variations in the observed data matrix. When PCA was performed with varimax rotation and Kaiser normalization, four components were extracted. The four components shown in Table 6 accounted for $90.6 \%$ of the geomorphic and hydrologic problems in the basin.

The Multiple Regression Analysis was then performed on the component defining variables (CDVs) from each of the components. The reasons for employing the multiple regression on the CDVs (which are independent variables) is because the original explanatory variables (i.e. the raw data) are highly related

Table 6. Varimax related component of morphometric factors of Obibia Basin.

\begin{tabular}{|c|c|c|c|c|c|}
\hline Variable Codes & Variable Label & Comp. I & Comp. II & Comp. III & Comp. IV \\
\hline $\mathrm{X}_{1}$ & SOR & -006 & -0.785 & 0.061 & $0.779^{*}$ \\
\hline $\mathrm{X}_{2}$ & SLE & 0.197 & 0.237 & 0.001 & 0.194 \\
\hline $\mathrm{X}_{3}$ & BLE & 0.887 & 0.197 & 0.009 & 0.003 \\
\hline $\mathrm{X}_{4}$ & MSL & 0.590 & 0.0112 & 0.326 & 0.128 \\
\hline $\mathrm{X}_{5}$ & MEL & 0.839 & 0.007 & 0.532 & 0.005 \\
\hline $\mathrm{X}_{6}$ & TSL & 0.398 & -0.295 & -0.000 & 0.240 \\
\hline $\mathrm{X}_{7}$ & BAP & 0.863 & -0.002 & 0.208 & 0.455 \\
\hline $\mathrm{X}_{8}$ & BFR & $0.974^{\star \star}$ & -0.172 & 0.898 & 0.006 \\
\hline $\mathrm{X}_{9}$ & BAR & 0.925 & 0.885 & 0.451 & 0.002 \\
\hline $\mathrm{X}_{10}$ & DRD & 0.006 & 0.003 & 0.409 & 0.005 \\
\hline $\mathrm{X}_{11}$ & SRF & 0.310 & 0.223 & 0.004 & $0.884^{* *}$ \\
\hline $\mathrm{X}_{12}$ & FFA & 0.909 & 0.240 & -0.002 & 0.006 \\
\hline $\mathrm{X}_{13}$ & CRA & 0.296 & 0.880 & 0.000 & 0.357 \\
\hline $\mathrm{X}_{14}$ & ERA & 0.023 & $0.937^{* *}$ & 0.556 & 0.001 \\
\hline $\mathrm{X}_{15}$ & BRE & 0.827 & -0.789 & $0.932^{* *}$ & -0.148 \\
\hline $\mathrm{X}_{16}$ & RRA & 0.005 & 0.784 & 0.167 & 0.367 \\
\hline $\mathrm{X}_{17}$ & BSL & 0.627 & 0.006 & 0.530 & 0.562 \\
\hline $\mathrm{X}_{18}$ & MAR & 0.661 & 0.699 & 0.281 & 0.250 \\
\hline $\mathrm{X}_{19}$ & MIR & 0.006 & 0.482 & $0.789^{*}$ & 0.352 \\
\hline Eigenvalue & & 7.35 & 5.54 & 3.88 & 1.69 \\
\hline$\%$ variable explained & & 36.77 & 27.72 & 23.41 & 2.80 \\
\hline Cum \% & & 36.77 & 64.49 & 87.89 & 90.6 \\
\hline
\end{tabular}

Significant loadings \pm 0.70 and above ${ }^{* *}$ component defining variables (CDV). 
Table 7. Result of the PCR analysis.

\begin{tabular}{cc}
\hline Statistic & Result \\
\hline Multiple correlation & 0.952 \\
Co-efficient of multiple determination $\left(\mathrm{R}^{2}\right)$ & 0.906 \\
Standard Error of Estimates (SEE) & 0.100 \\
\hline
\end{tabular}

Table 8. Relative contributions of the variables.

\begin{tabular}{cccc}
\hline Variable & Multiple $\mathbf{R}$ & $\mathbf{R}^{2}$ & $\mathbf{R}^{2}$ Change \\
\hline $\mathrm{X}_{8}$ & 0.801 & 0.642 & 64.2 \\
$\mathrm{X}_{14}$ & 0.870 & 0.757 & 11.5 \\
$\mathrm{X}_{15}$ & 0.922 & 0.850 & 9.3 \\
$\mathrm{X}_{11}$ & 0.952 & 0.906 & 5.6 \\
\hline
\end{tabular}

which may cause inaccurate estimations of least square regression coefficients. Furthermore, the dimensionality of the regressions is reduced by taking only the CDVs for prediction. The intention of using PCR was to extract the underlying effects in the $\mathrm{X}$ data and to use these to predict the $\mathrm{Y}$ values. In this way, we could guarantee that only independent effects were used and local variance noise effects were excluded and this expectedly improves the quality of the model significantly. The dependent variable is the basin area with the loading of 0.925 in the first component. The PCR equation expressing the closest possible relationship between the basin area and the 4 specified variables is

$$
\mathrm{Y}\left(\mathrm{X}_{9}\right)=1.24 \times 0.46 \mathrm{X}_{8}+0.26 \mathrm{X}_{14}+0.32 \mathrm{X}_{15}+0.20 \mathrm{X}_{11}
$$

The summary of the result is shown in Table 7.

On the calculation of the relative importance of the variables, we computed successive values of the multiple correlation coefficient obtained by introducing successive independent variables at each computation [4] i.e. Ry.x, Ry. $\mathrm{X}_{1} \mathrm{X}_{2}$, $R y, X_{1} X_{2} X_{3}$ and Ry. $X_{1} X_{2} X_{3} X_{4}$. The difference between the squared multiple correlation $\left(R^{2}\right)$ is then regarded as the contribution of each variables (Table 8).

\subsection{Discussion}

Obibia river basin was found to be a $4^{\text {th }}$ order basin. The stream order was plotted against the stream numbers and logarithm of stream numbers against order are presented in Figure 2 and Figure 3. In Figure 2 the straight line relationship of points is not so perfect as almost all the points are outside the straight line, but when the points were transformed through logarithm the lines conformed to the straight line, but again not so perfect, indicating that some structural disturbances have started to exhibit themselves in the basin. The total stream length of the basin is $102.25 \mathrm{~km}$. The regression of the logarithm of the stream length (log $\mathrm{Lu}$ ) versus order $(\mathrm{u})$ for the basin is presented in Figure 4. The graph has a "snake" shape other than normal straight line relationship of an ideal river. This is further corroborated in the plotting of the mean stream length of various or- 
ders against the orders (Figure 5). This graph revealed that points 1, 2, 4 (i.e. orders 1,2 and 4), are outside the line, the effect of structural abnormality was more pronounced in order 2 . On the bifurcation ration $\left(R_{b}\right)$ which is a dimensionless property, it shows only a small variation of different regions with different environment except where powerful geological control dominates [5]. Values of $\mathrm{Rb}$ typically range from the theoretical maximum of 3 to a maximum of 5. Newman [6] was of the view that lower $\mathrm{Rb}$ values are characteristic of basins which suffers less structural disturbance and drainage pattern that has not been distorted due to the structural imbalances. Conversely high $\mathrm{Rb}$ value indicates that the flow of energy is low which in turn gives different time for infiltration and ground water recharge, as well as, low probability of flooding and vice versa [7].

The mean $\mathrm{Rb}$ of the basin is 4.09 which falls within the $3-5$ range of basin with stable geologic structure which do not present distorted drainage pattern. However, the $\mathrm{Rb}$ of various orders vary indicating a level of distortion probably as a result of the on-going physical development taking place at various parts of the basin. For example, the highest $\mathrm{Rb}(5.00)$ is found between $2^{\text {nd }}$ order and $3^{\text {rd }}$ order indicating strong stability, while the $\mathrm{Rb}(3.00)$ is found between $3^{\text {rd }}$ order and $4^{\text {th }}$ order and this indicates a higher risk of flooding in that part of the basin. The basin area of our study area is $84 \mathrm{sq} \cdot \mathrm{km}$ which is a relatively medium-sized basin likely to intercept high volume of rainfall and therefore higher risk of flooding. The drainage density of 1.22 indicates that it has a somewhat high permeability as would be seen from the Nanka and Ebenebe sands formation of the area, which easily infiltrate water. The elongation ratio of any basin ranges from $0.6-0.8$. Higher values occur in areas of high relief and steep ground slope. These values are further categorized as circular $(>0.9)$ and oval $(0.9-8.0)$ and less elongated $(<0.7)$. Flood flow in elongated basins is easier to manage than that of circular basins that are more prone to flash flood and higher discharge. The basin's elongation ratio of 0.57 expresses elongation where flooding can be easily managed, what this means is that flood in the basin can be easier tackled. The circulatory ratio of natural basins range from $0.4-0.5$ and incidentally this basin's ratio of 0.41 falls within this range showing that the basin is very strongly elongated. This further shows that it has a reasonably high level of permeability as could also be seen from its medium to low relief which is between $100 \mathrm{~m}$ to $250 \mathrm{~m}$ above sea level.

The basin relief of the basin $(600 \mathrm{~m})$ goes to validate the medium to low relief found in the analysis of elongation ratio.

Table 6 shows the varimax rotated value of the morphometric parameters of the basin, using PCA it is seen that the parameter with the highest loading in Component 1 is $\mathrm{X}_{8}$ (BFR) of 0.974 . This means that the bifurcation ratio is the strongest morphometric parameter in the basin. From the analysis of the bifurcation ratio, it was found that the $\mathrm{Rb}$ of the orders are not the same; 4.25 (between $1^{\text {st }}$ and $2^{\text {nd }}$ order), 5.00 (between $2^{\text {nd }} 3^{\text {rd }}$ order) and 3.00 (between $3^{\text {rd }}$ and $4^{\text {th }}$ order) and the mean $\mathrm{Rb}$ of the basin of 4.09 , were calculated, generally the 
entire basin is between the high and low values indicating that some structural problems are already manifesting. The situation at the mouth of the Obibia basin with $\mathrm{Rb}$ of 3 reveals a predisposition to flood incidents. Most disturbing is that urban development is fast taking place in the entire basin although it is presently more pronounced at the middle and lower section of the basin where the present Awka town is located. Furthermore, $\mathrm{X}_{14}$ (ERA) (0.937) shows that the elongation ratio is a parameter to be closely observed. Although with its value of 0.57 , it is slightly outside the range of $0.4-0.5$ for natural basins. This, therefore, means that the flood condition is being created by the present physical development in many parts of the basin. Component III has $\mathrm{X}_{15}$ (BRE) (0.958) as the parameter with the highest loading, Basin relief was calculated to be $600 \mathrm{~m}$, although that is higher than the general situation but goes to indicate that there are some areas of the basin that are high, as could be seen around Gama Hill east of the basin and in Agulu where the height relief is about $750 \mathrm{~mm}$ This situation are seen in patches in the basin. This elevation around Agulu is one of the reasons for erosion and excessive sedimentation which are the features of the area. Finally, component IV has XII (SFR) with highest loading of 0.884 . Stream Frequency which is an indication of drainage pattern depends mainly on the lithology of the basin. It is an index of various stages of landscape evolution. The stream frequency of the area is being altered as vegetation is daily removed for various forms of construction. The high value of stream frequency and drainage density of the area strongly indicate possibility of flooding in the area especially at the built up area. The result of PCR on the four isolated morphometric properties shows that all of them operating together contributed $90.6 \%$ to the geomorphic and hydrologic problems within the area of the basin. On the calculation of the relative importance of the variables, it was seen that $\mathrm{X}_{8}$ (BFR) contributed as high as $64.2 \%$ of the $90.6 \%$ (which is $70.9 \%$ ) of the contribution of the four parameters). The contributions of others include $\mathrm{X}_{14}$ (ERA) - $11.5 \%, \mathrm{X}_{15}$ (BRE)9.3\% and $\mathrm{X}_{11}$ (SRF) - 5.6\%. This, therefore, means that greater attention will be contributed on the bifurcation ratio of the basin considering the on-going intensive construction of roads, houses, and increase in the area of paved surfaces and of course, destruction of the vegetation.

\section{Conclusion}

We have tried to examine the linear, areal and relief properties of the Obibia basin and related them to the on-going physical development of the area within the basin which covers a good part of the Awka capital territory. The revelation of four important morphometric factors that result in some geomorphic and hydrologic problems of the area is instructive. Out of these variables, bifurcation ratio contributes over $70 \%$ of all the contributions of the isolated factors. This means that this parameter should be more closely examined periodically. It has been concluded that adequate planning of the Awka capital territory environment may not achieve good result without considering these isolated factors. 


\section{References}

[1] Ajibade, L.T., Ifabiyi, I.P., Iroye, K.A. and Ogunteru, S. (2010) Morphometric Analysis of Ogunpa and Ogbere Drainage Basins, Ibadan, Nigeria. Ethiopian Journal of Environmental Studies and Management, 3, 13-19. https://doi.org/10.4314/ejesm.v3i1.54392

[2] Eze, B.E. and Effiong, J. (2010) Morphometric Parameters of the Calabar River Basin: Implication for Hydrologic Processes. Journal of Geography and Geology, 2, $18-26$.

[3] Abua, M. and Abua, L. (2013) Hydraulic Characteristics and Relationships of Oromineke Basin, Diobu, Port Harcourt. Journal of Hydraulic Engineering, 4, 44-52.

[4] Anyadike, R.N.C. (2010) Statistical Methods for the Social and Environmental Sciences. Spectrum Books Limited, Ibadan.

[5] Strahler, A.N. (1964) Quantitative Geomorphology of Drainage Basins and Channel Networks. In: Chow, V.T., Ed., Handbook of Applied Hydrology, McGraw-Hill, New York, 439-479.

[6] Newman, C. (2013) Bifurcation Ratio as Important Linear Property of Drainage Basin. Continental Hydrology, 6, 133-140.

[7] Al Saud, S.K. (2009) Energy Flow in Drainage Basins. Journal of Agriculture and Forestry, 2, 69-71. 